\title{
Pemulihan Ekonomi Di Masa Pandemi Melalui Pemberdayaan Kampung Produktif Dengan Pendekatan Socialpreneur
}

\author{
Nurul Lathifah ${ }^{1}$, Silfia Herlina ${ }^{2}$ \\ Universitas Islam Negeri Sunan Ampel Surabaya ${ }^{1}$, Universitas Airlangga ${ }^{2}$ \\ n.lathifah@uinsby.ac.id ${ }^{1}$, silfia.herlina-2018@feb.unair.ac.id ${ }^{2}$
}

\begin{abstract}
Abstrak: Masa pandemi Covid-19 menyebabkan banyak negara mengalami kemerosotan perekonomian sehingga menimbulkan kesenjangan sosial, banyaknya warga yang terkena pemutusan hubungan kerja. Pengentasan kemiskinan dapat dimulai dari lingkup skala mikro yakni adanya pembentukan kampung produktif dengan menggunakan pendekatan Socialpreneur yang bertujuan memberdayakan masyarakat guna mendukung upaya pengentasan kemiskinan warga di pedesaan atau perkampungan melalui pendekatan gender, yakni pemberdayaan kaum perempuan melalui Program Kampung Produktif (PKP). Metode yang digunakan dalam penelitian ini adalah penelitian kualitatif dengan menggunakan pendekatan naratif. Dengan adanya kegiatan tersebut diharapkan kaum perempuan memiliki jiwa kewirausahaan dengan menghasilkan produk yang bernilai ekonomis. Sehingga melalui program tersebut seseorang mampu menghasilkan tambahan pendapatan dengan produk bernilai ekonomi tinggi melalui kemapanan teknologi madani.
\end{abstract}

Kata-kata Kunci: Perekonomian pandemi Covid-19, Kampung Produktif, Socialpreneur

Berdasarkan data dari Badan Pusat Statistik (BPS) menjelaskan bahwa jumlah persentase kemiskinan penduduk bulan Maret Tahun 2020 mencapai 9,78 persen, terjadi peningkatan kemiskinan 0,56 persen dibandingkan pada bulan September Tahun 2019, serta terjadi peningkatan sebesar 0,37 persen untuk bulan Maret Tahun 2019. Selain itu, data Sakernas 2019 menunjukkan bahwa pelaku usaha mandiri sebesar 26 juta pekerja, temuan di lapangan terdapat 10 juta pekerja yang berhenti bekerja. Sedangkan pekerja bebas sebanyak 55 persen tidak memiliki pekerjaan dan 38 persen order pekerjaan berkurang, sehingga jika diproyeksikan dengan data Sakernas 2019 menjelaskan bahwa jumlah pekerja bebas/pekerja keluarga jumlahnya sebesar 26,5 juta pekerja yang berarti bahwa terdapat 15 juta pekerja bebas/keluargaakan menganggur dari kelompok usaha mandiri (Ramadhani :2020).

Usaha mengatasi permasalahan sosial dengan menggunakan pendekatan entrepreneurship menjadi sebuah solusi yang efektif dalam mengentas kemiskinan (Wuryandani :2019), ditandai dengan bermacam bentuk kegiatan kewirausahaan sosial, seperti beberapa wilayah yang ada pada kota Surabaya meliputi kampung handicraft dibentuk oleh komunitas ibu-ibu yang terampil dalam membuat kerajinan. Dirintis tahun 2004 hingga sekarang telah menciptakan beraneka produk yang layak jual seperti tudung saji, dompet lukis, sapu tangan, hiasan meja, kotak tissue, tas pesta, bross, dompet, kipas dan aneka kerjainan lainnya. Selain itu terdapat contoh lain seperti kampung keripik tempe di daerah Sukomanunggal berdiri sejak tahun 1983 (Surabaya, liputan 6.com). 
Sesuai pendekatan kewirausahaan yang telah dilakukan diatas, terutama pada musim pandemi Covid-19 sangat membantu manambah penghasilan bagi warga masyarakat yang terdampak Covid-19. Socialpreneur adalah langkah terobosan yang memadukan spirit untuk tujuan sosial dengan keuletan dalam berinovasi serta menjalankan usaha (Bin Tahir :2020). Bill Drayton (pendiri Ashoka Foundation) dalam buku Wuryandani (2019) menjelaskan bahwa terdapat dua kunci kewirausahaan sosial diantaranya (1) adanya inovasi sosial yang mampu mengubah sistem pada masyarakat dan (2) hadirnya perseorangan yang bervisi, kreatif, berjiwa wirausaha (entrepreneurial) dan beretika yang berada dibelakang gagasan inovatif tersebut. Hulgard (2010) menyatakan kewirausahaan sosial secara komprehensif: "Social entrepreneurship can be defined as the creation of social value that is produced in collaboration with people and organisation from the civil society who are engaged in social innovation that usually imply an economic activity". Berarti bahwa kewirausahaan sosial terdiri dari empat elemen utama yaitu social value, civil society, innovation and economic activity. Pertama, nilai sosial adalah elemen khas kewirausahaan sosial dengan menciptakan manfaat sosial yang nyata bagi masyarakat dan lingkungan sekitarnya. Kedua, masyarakat madani ialah ciri kewirausahaan sosial, umumnya berasal dari inisiatif dan partipasi masyarakat madani atau sipil dengan mengoptimalkan modal sosial yang ada di kalangan masyarakat. Ketiga, inovasi yang menjadi instrumen bagi kewirausahaan sosial untuk memecahkan masalah sosial dengan cara-cara inovatif, dengan cara memadukan kearifan lokal dan inovasi sosial. Keempat, aktivitas ekonomi yang menentukan tingkat kinerja kewirausahaan sosial.

Adapun penelitian sebelumnya terkait socialpreneur diantaranya meliputi Firdaus (2014), Nur (2014), Widodo (2014), Budiwati (2017), Putri (2017), Murweni (2018), Moenawar (2019), Saputri (2019), Adnan (2020), Bin Tahir (2020), Juniyesnani (2020), Muryanti (2020). Beberapa penelitian tersebut menjelaskan mengenai socialpreneur yang menjadi treatment dalam pengentasan kemiskinan namun masing-masing objek penelitian berbeda. Bin Tahir (2020) menjelaskan bahwa perbaikan sumber daya manusia melalui kewirausahaan terhadap masyarakat lokal di Desa Argosari guna peningkatan kualitas wisata, berjalan dengan baik sesuai petunjuk pemerintah setempat sehingga berdampak pada perkembangan wisata di daerah tersebut.

Penelitian ini difokuskan untuk menjawab pertanyaan mengenai bagaimana pemulihan ekonomi di masa pandemi melalui pemberdayaan kampung produktif dengan pendekatan socialpreneur? Dengan tujuan untuk menjelaskan pemulihan ekonomi di masa pandemi melalui pemberdayaan kampung produktif dengan pendekatan socialpreneur. Penelitian ini disusun dengan metode naratif kemudian menyimpulkan konsep-konsep yang menjadi fokus pembahasan hingga diperoleh hasil bahwa dengan kegiatan kewirausahaan sosial berpengaruh terhadap tingkat keberdayaan masyarakat. 


\section{METODE}

Metode yang digunakan dalam penelitian ini adalah penelitian kualitatif dengan menggunakan pendekatan naratif. Menurut Creswell (2007), tipe-tipe pendekatan naratif meliputi biografi yang berfokus untuk memahami kehidupan seorang individu. Penelitian biografi mengungkapkan turning point atau epipani yang merupakan pengalaman menarik yang sangat mempengaruhi atau mengubah hidup seseorang. Tahapan tersebut akan disajikan menggunakan naratif yang mengerucutkan pada pola-pola tertentu. Fokus penelitian adalah kampung produktif yang menjadi aktor penggerak Sociopreneurship.

\section{HASIL DAN PEMBAHASAN}

Gregory Dees dalam penelitian Puspitasari (2019) menjelaskan bahwa kewirausahaan sosial berbeda dengan kewirausahaan bisnis. Kewirausahaan sosial mempunyai tujuan eksplisit berdasarkan pada sebuah gerakan yang didorong oleh semangat untuk menolong orang lain dan membuat perubahan untuk kebaikan bagi masyarakat. Wirausaha sosial adalah mereka yang memiliki pengetahuan modal (Sumber Daya Manusia), modal sosial, dan keterampilan sosial, yang mengubah masalah sosial menjadi inovasi sosial. Cara terbaik untuk mengukur kewirausahaan sosial bukan dengan menghitung jumlah keuntungan yang dihasilkan tetapi pada tingkat dimana kegiatan ekonomi juga menghasilkan nilai-nilai sosial. Selain itu, menurut Gregory Dess, kewirausahaan sosial adalah kombinasi dari antusiasme dalam kegiatan sosial, yang dikombinasikan dengan tekad, inovasi, dan disiplin, hampir sama dengan apa yang berkembang di dunia bisnis. Kegiatan kewirausahaan sosial tidak hanya untuk mencari keuntungan, tetapi juga bagaimana menggabungkan kegiatan mencari keuntungan dengan kegiatan yang bertujuan nilai sosial.

Perriri dan Vurro (2006) menjelaskan bahwa social entrepreunership menginisiasi perubahan sosial yang terjadi pada masyarakat. Peran inisiator membuat mereka mempunyai inovasi sosial dan kapasitas dalam pengembangan untuk memberikan dampak sosial melalui social entrepreneurship. Sedangkan menurut Maulinda (2018) menjelaskan bahwa kewirausahaan sosial sebagai proses dinamis diciptakan dan dikelola oleh individu atau tim yang berusaha memanfaatkan inovasi sosial dengan pola pikir kewirausahaan untuk menciptakan nilai sosial baru di pasar dan masyarakat.

Konsep social entrepreneurship Ventures/SEVs dianalisis dalam empat area. Pertama, visi, misi, dan nilai organisasi yang menjelaskan bahwa area ini merupakan sebuah social enterprise adalah "jantung" organisasi dimana jiwa dan kepercayaan tertanam di dalamnya. Dalam ketiga hal tersebut, sebuah social enterprise menjelaskan inovasi apa yang dilakukan, penerima manfaat, dan hasil utama dari sebuah kegiatan social entrepreneurship. Kedua, kesempatan wirausaha dan inovasi sosial yang berarti peluang social entrepreneurship dapat diidentifikasi dari 
proses yang muncul dengan adanya vision-oriented factors (or internal factors) and crisis-oriented factors (or external factors). Kedua faktor tersebut berasal dari pengalaman pribadi dan pengalaman sebelumnya atau pengalaman yang pernah dialami oleh individu. Ketiga, model kewirausahaan sosial. Tahap ini berada di antara bisnis dan non-profit, fokusnya adalah melihat sinergi, bagaimana transfer kemampuan, pengetahuan, dan praktik dalam bisnis atau sosial partner dan dampaknya secara umum. Model kewirausahaan sosial ini mengidentifikasi partisipasi dan struktur kelembagaan yang menawarkan solusi inovatif. Keempat, hasil dan dampak sosial. Hasil sosial dapat diidentifikasi dengan tiga poin pencipataan, yaitu penciptaan lapangan pekerjaan, hasil sosial terhadap akses informasi, dan adanya perubahan sosial yang terjadi, seperti pola interaksi, pendekatan partisipatif, peningkatan kesejahteraan serta integrasi sosial.

Berikut dibawah ini merupakan tampilan skema deskriptif proses kewirausahaan sosial yang dapat digunakan dalam menjelaskan bagaimana pemulihan ekonomi saat pandemi melanda Indonesia yang dapat dilakukan dengan melakukan pendekatan-pendekatan melalui beberapa tahapan.

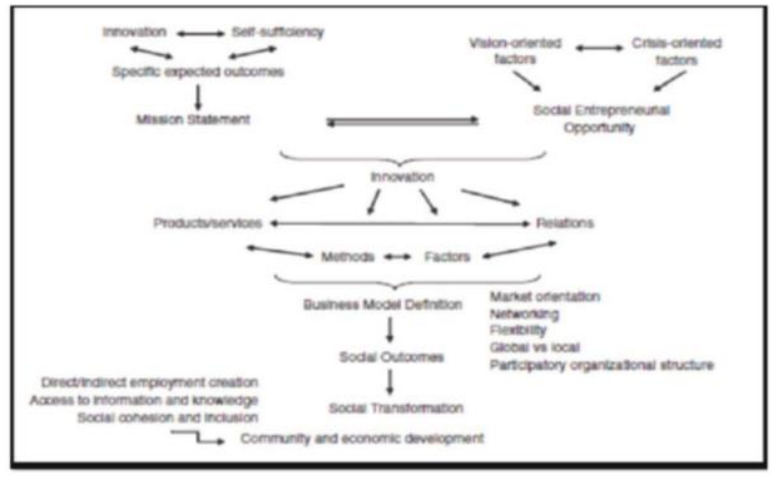

Gambar 1. Skema Deskriptif Proses Kewirausahaan Sosial Tahapan Perkembangan Kewirausahaan Sosial

Dalam buku yang berjudul "The Rise of The Social Entrepreneur" Leadbeater (1997) menjelaskan tahapan perkembangan kewirausahaan sosial yang digambarkan oleh gambar di bawah ini:

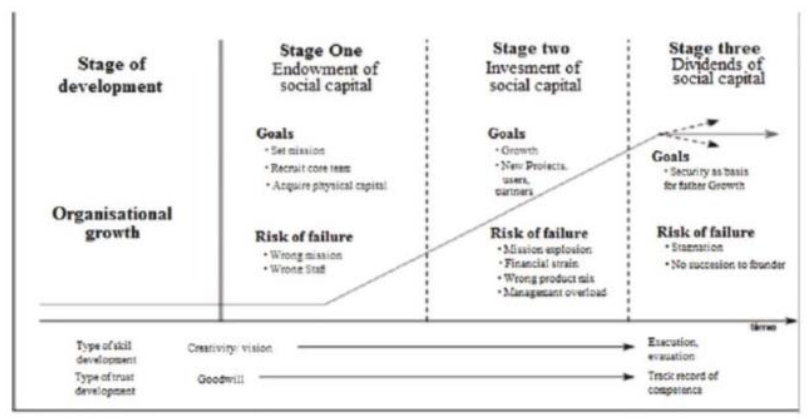

Gambar 2. Tahapan Perkembangan Kewirausahaan Sosial 
Gambar di atas menjelaskan tiga tahapan yang dilalui dalam perjalanan kewirausahaan sosial, diantaranya adalah:

1. Tahapan pertama

Dukungan sosial yang mempunyai empat aspek yang perlu dilalui dalam proses kewirausahaan sosial. Empat aspek tersebut meliputi dukungan yang terbentuk dari komunitas atau masyarakat sekitar, pentingnya penetapan tujuan ataupun sasarannya.

2. Tahapan kedua

Organisasi mulai dikenal sehingga diharapkan mampu menghasilkan gagasan baru, pengguna yang baru, dan rekananrekanan baru demi tumbuh dan berkembangnya organisasi.

3. Tahapan ketiga

Organisasi akan mengalami keadaan stagnan setelah pertumbuhan yang masif di tahapan kedua. Sasaran pada tahap ini adalah menjaga atau mengamankan program dan apa-apa yang sudah ada sebagai tumpuan guna kemajuan yang lebih jauh, dengan kata lain mengamankan keberadaan produk sehingga memerlukan evaluasi secara berkala.

Kemampuan perempuan dalam menghasilkan pendapatan melalui kegiatan ekonomi produktif (berwirausaha) berdampak pada pendapatan keluarga mereka. Karena pendapatan keluarga tidak hanya bersumber dari pendapatan suami sebagai kepala keluarga, tetapi juga dari pendapatan perempuan ketika isteri terlibat dalam kegiatan ekonomi. Semakin besar pendapatan isteri berarti semakin besar pula kontribusinya terhadap pendapatan keluarga secara keseluruhan, yang pada gilirannya tidak hanya berdampak pada perbaikan kemampuan pemenuhan kebutuhan keluarga, tetapi juga punya peluang mengangkat taraf hidup keluarga sehingga keluar dari lingkaran kemiskinan (Seebens, 2009). Karena itu upaya penurunan tingkat kemiskinan dapat dilakukan melalui kegiatan yang berorientasi pada peningkatan pendapatan perempuan (Khan, 2013). Sebelumnya penelitian Shin (2010) dengan unit analisis sejumlah negara Asia merekomendasikan bahwa bahwa peningkatan perempuan dalam ekonomi dapat dijadikan salah satu kebijakan strategis dalam upaya menurunkan tingkat kemiskinan. Bukan hanya melalui keterlibatan dalam kegiatan ekonomi saja tetapi juga peran perempuan dalam mengurangi tingkat kemiskinan dapat diwujudkan melalui kemampuan mereka dalam mengatur keuangan rumah tangga. (Adnan: 2020)

Salah satu contoh Kawasan Dolly di Surabaya ini dulunya terkenal dengan kawasan hiburan malam (lokalisasi prostitusi), hingga pada akhirnya ditutup pada tahun 2014. Roda perekonomian masyarakat terdampak penutupan tempat itu harus tetap berputar. Dengan mendapat penyuluhan/pelatihan dari Pemerintah Kota Surabaya dan elemen masyarakat yang peduli pada kawasan ini, mereka diberi pemahaman tentang pentingnya mencari rezeki dengan cara yang baik dan dari tempat yang baik. Kesadaran untuk memeroleh penghasilan dengan usaha 
sendiri, tanpa bergantung dari lokalisasi prostitusi, tumbuh dan berkembang dengan baik. Setelah itu, mulailah digali peluang ekonomi di Kawasan Dolly ini. Pelatihan ekonomi kreatif yang dilaksanakan telah menciptakan UMKM yang berdaya saing tinggi dengan banyak varian produk. Mulai dari olahan makanan/minuman, kerajinan tangan, batik, minyak rambut, sandal/sepatu, sablon, udeng, dan lain sebagainya. Pelatihan ekonomi kreatif ini juga didukung dengan upaya promosi berkelanjutan yang dilaksanakan oleh Pemerintah Kota Surabaya dengan keikutsertaan UMKM Dolly dalam banyak event dan pameran. Dengan demikian, jalur penjualan produk terbuka lebar.

Program Kampung Produktif bisa dilakukan melalui program pemerintah, kerjasama dengan perguruan tinggi, lembaga/organisasi masyarakat, dan lain sebagainya dalam meningkatkan ekonomi masyarakat dengan pendekatan socialpreneur. Proses pembentukan kampung produktif dapat dilihat dalam Gambar 3.

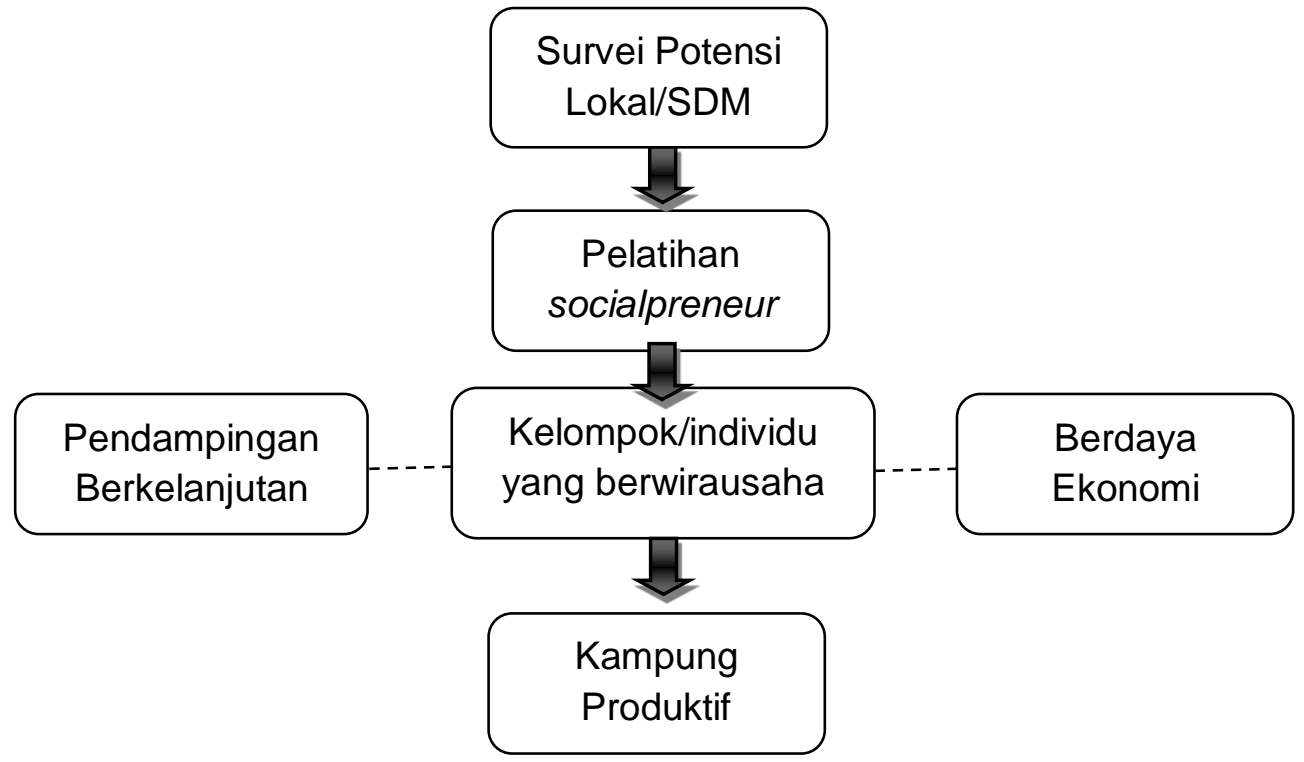

Gambar 3. Alur Program Kampung Produktif

Program dimulai dengan survei potensi kampung tersebut. Potensi tiap kampung berbeda-beda, seperti sebagai berikut:

1. Potensi wisata (pengembangan ekonomi melalui wisata lokal) seperti Desa Wisata Sekapuk, Gresik, kawasan mangrove, wonorejo, Surabaya.

2. Potensi Pangan (pengembangan ekonomi melalui usaha pangan) seperti kampung keripik tempe, kampung kue, kampung tempe di surabaya,

3. Potensi kerajinan tangan (pengembangan ekonomi kreatif handycraft) seperti di kampung handycraft wonorejo Surabaya, kampung bordir, kampung tas di Surabaya

4. Potensi Edukasi (pengembangan ekonomi Pendidikan) seperti Kampung Inggris di Kediri, Kampung Ilmu di Surabaya

5. Dan lain sebagainya 
Karena saat ini masih dalam masa pandemi maka dalam hal survei potensi harus tetap menerapkan protokol Kesehatan.

Setelah mensurvei potensi kawasan/kampung kemudian dilakukan pelatihan socialpreneur yang sesuai dengan potensi yang ada di kampung tersebut. Pelatihan ini meliputi pemberian motivasi, penyuluhan kewirausahaan, melihat pangsa pasar, desain produk, branding produk, pelatihan pembuatan/pengolahan potensi (bisa pelatihan mengolah/membuat produk), dan metode pemasaran berbasis teknologi. Dalam pelatihan ini bisa dilakukan secara virtual untuk membatasi kerumunan. Pelatihan virtual bisa dilakukan melalui zoommeting/googlemeet untuk pertemuan, penggunaan youtube untuk praktik pengolahan produk maupun materi pelatihan dalam bentuk video, penggunaan WAG untuk diskusi dan share berbagai ilmu (marketing, branding produk, desain produk, dan lain sebagainya) serta pemantauan tindak lanjut. Dengan memanfaatkan teknologi yang ada saat ini diharapkan pelatihan socialpreneur bisa tersampaikan dengan baik dan optimal. Sehingga dengan diberikannya kegiatan pelatihan socialpreneur yang berfokus pada pemanfaatan potensi lokal menjadi produk yang bernilai lebih (ekonomis) akan tercipta Kampung Produktif. Socialpreneur menjadi sangat penting mengingat keuntungan yang diperoleh bukan hanya untuk kepentingan individu saja tetapi lebih ditujukan untuk kemakmuran masyarakat.

Dari hasil pelatihan tersebut diharapkan akan terbentuk kelompok usaha ibu-ibu dalam menerapkan ilmu yang telah diberikan untuk memulai berwirausaha dalam meningkatkan perekonomian individu dan warga kampung dengan terus didampingi oleh pengelola program (baik pemerintah/lembaga/perguruan tinggi). Sehingga dengan adanya kelompok ibu-ibu wirausaha tersebut dapat meningkatkan kesejahteraan warga di masa pandemi dengan adanya Kampung Produktif Berdaya Ekonomi. Oleh karena itu, hal ini harus terus diupayakan munculnya socialpreneur lainnya untuk membuat masyarakat semakin berdaya dan bangkit pada masa pandemi ini serta meningkatkan perekonomian bangsa.

\section{KESIMPULAN}

Pemulihan ekonomi di masa pandemi dapat dilakukan pembentukan kampung produktif dengan menggunakan pendekatan socialpreneur yang bertujuan memberdayakan masyarakat guna mendukung upaya pengentasan kemiskinan warga di pedesaan atau perkampungan melalui pendekatan gender, yakni pemberdayaan kaum perempuan melalui Program Kampung Produktif (PKP). Program dimulai dengan survei potensi kampung yang memanfaatkan potensi lokal menjadi produk yang bernilai ekonomis. Kemudian dilakukan pelatihan virtual socialpreneur yang meliputi pemberian motivasi, penyuluhan kewirausahaan, melihat pangsa pasar, desain produk, branding produk, pelatihan pembuatan/pengolahan potensi (bisa pelatihan 
mengolah/membuat produk), dan metode pemasaran berbasis teknologi. Dari hasil pelatihan tersebut maka akan terbentuk kelompok usaha ibu-ibu yang memulai berwirausaha. Dengan adanya kelompok ibu-ibu wirausaha tersebut maka akan terbentuk kampung produktif. Sehingga dengan adanya Program Kampung Produktif ini diharapkan dapat meningkatkan kesejahteraan masyarakat dan perekonomian bangsa pada masa pandemi ini.

\section{DAFTAR PUSTAKA}

Adnan, G., \& Amri, K. (2020). Apakah Pendapatan Perempuan Dapat Mengurangi Kemiskinan? Bukti Data Panel di Indonesia. Inovbiz: Jurnal Inovasi Bisnis, 8(1), 64-71.

Bin-Tahir, S. Z. (2020). Pengentasan Kemiskinan Melalui Socialpreneur.

Budiwati, H. (2017). Strategi Social Entrepreneurship Berbasis Keunikan Lokal Membangun Keunggulan Bersaing Di Kawasan Senduro Lumajang. Indonesia Journal of Entrepreneurship, 3(1), 1-23.

Creswell, John W. (2007). Qualitative Inquiry and Research Design: Choosing Among Five approaches /2nd ed.California: Sage Publications, Inc.

Firdaus, N. (2014). Pengentasan kemiskinan melalui pendekatan kewirausahaan sosial. Jurnal ekonomi dan Pembangunan, 22(1), 55-67.

Hulgard. Lars, (2010). Discourses of Social Entrepreneurship- Variation of The Same Theme Emes European Research Network.

Juniyesnani, A. B., \& Suranto, S. P. (2020). Pemberdayaan Masyarakat Menuju Social Entrepreneur Pada Pasar Papringan Dusun Ngadiprono, Desa Ngadimulyo, Kecamatan Kedu, Temanggung. Doctoral dissertation, Universitas Muhammadiyah Surakarta.

Khan, S. (2013). Women's empowerment through poverty alleviation: a sociocultural and politico-economic assessment of conditions in Pakistan. International Journal of Academic Research and Reflection 1(1), 16- 40.

Komala, L., Budiyanto, A., Wibowo, W. A., Praditya, A., \& Pamungkas, I. B. (2020). Membangun Kreativitas dan Kemandirian Masyarakat di Masa Pandemi COVID-19. DEDIKASI PKM, 1(2), 20-24.

Leadbeater, Charles. (1997). The Rise of The Social Entrepreneur. London: Demos.

Liputan6.com. (2 Januari 2020). Citing Internet sources URL Https://surabaya.liputan6.com/read/4060976/6-kampungsurabaya-dengan-produk-unggulannya.

Maulinda, K. (2018). Proses Pengembangan Sosial Enterprise Agriculture: Studi Biografi Pada Agradaya. Jurnal Studi Pemuda, 7, 133-146.

Metrotimes. (2020). Program Bu Risma Kampung Surabaya Smart City, Menggali Potensi dan Kreativitas Warga Kampung Surabaya. Citing Internet sources URL https://metrotimes.news/nasional/program-bu- 
risma-kampung

surabaya-smart-city-menggali-potensi-dankreativitas-warga-kampung-surabaya/.

Moenawar, M. G. (2019). Komunikasi Pembangunan Partisipatif untuk Kewirausahaan Sosial pada Taman Teknologi Pertanian di Kabupaten Lamongan. In Seminar Nasional Sosial Ekonomi 2019 (p. 104).

Müller, F. (2015). Sustainable Development Goals (SDGs). PERIPHERIE - Politik •Ökonomie• Kultur. https://doi.org/10.3224/peripherie.v35i140.23001.

Murweni, I., \& Yusuf, R. (2018). Membangun Sociopreunership Dan Inovasi Produk Melalui Nilai-Nilai Kearifan Lokal Pada Kelompok Tani Tirta Mulya Desa Cipinang Kecamatan Cimaung-Kabupaten Bandung. In Seminar Nasional Pengabdian Kepada Masyarakat (PKM) (Vol. 1, No. 1, pp. 484-501).

Muryanti, M. (2020). Towards social entrepreneurship in the village through village-owned enterprises. Society, 8(1), 163-174.

Nur, F. (2014). Pengentasan Kemiskinan Melalui Pendekatan Kewirausahaan Sosial (Poverty Alleviation Through Social Entrepreneurship Approach). Jurnal Ekonomi dan Pembangunan, 22(1), 55-67.

Perrini, Francesco and Clodia Vurro. (2006). Social Entrepreneurship: Innovation and Social Change Across Theory and Practice. Pp 5785 dalam Mair, Robinson and Hockerts. Social Entrepreneurship. New York : Palgrave Macmillan.

Puspitasari, D. C. (2019). Kewirausahaan Sosial: Dalam Konsep Dan Terapan. Diskusi Umum. Yogyakarta, Indonesia.

Putri, L. I. (2017). Reduksi Kemiskinan Melalui Sosiopreneurship. Islamic Review: Jurnal Riset dan Kajian Keislaman, 6(1), 48-68.

Ramadhani, P. I. (2020). Penduduk Miskin Indonesia Naik Jadi 26,42 Juta Orang di Maret 2020. Citing Internet sources URL https://www.liputan6.com/bisnis/read/4305950/penduduk-miskinindonesia-naik-jadi-2642-juta-orang-di-maret-2020.

Saputri, R. U., Hendarso, Y., \& Taqwa, R. (2019). Strategi Social Entrepreneurship Dalam Pengembangan Ekonomi Kreatif Berbasis Local Wisdom (Studi Pada Kelompok Pengrajin Eceng Gondok "Melati" Plaju Kota Palembang). Doctoral dissertation, Sriwijaya University.

Sawitri, D. (2020). Penggunaan Google Meet Untuk Work From Home Di Era Pandemi Coronavirus Disease 2019 (Covid-19). Prioritas: Jurnal Pengabdian Kepada Masyarakat, 2(01), 13-21.

Seebens, H. (2009). The contribution of female non-farm income to poverty reduction. International Association of Agricultural Economists Conference, Beijing, China, August 16-22.

Shin, K-Y. (2010). The effect of labor force participation by women on family income inequality in Korea, Japan, and Taiwan. Korean Social Science Journal, 27(1), 27- 55. 
Widodo, S., \& Nugroho, T. R. (2014). Model Pendidikan Kewirausahaan Bagi Santri Untuk Mengatasi Pengangguran di Pedesaan. Jurnal MIMBAR, 30(2).

Wuryandani, D. (2019). Bagian Pertama Peran Kewirausahaan Sosial Dalam Meningkatkan Perekonomian Daerah. Pengembangan Kewirausahaan untuk Pemberdayaan Ukm Daerah, 11.

Zulfa, L. L., Mujibah, M., \& Rajaguguk, Z. F. (2020). Pelatihan Penggunaan Perangkat Berbasis Internet dalam Pengumpulan Data Penelitian Masa Pandemi COVID-19. Kilas Artikel Abstrak, 1(2),143-158. 